Sustinere

Journal of Environment and Sustainability

Volume 1 Issue 1 (2017) 10-22

Print ISSN: 2549-1245 Online ISSN: 2549-1253

Website: https://sustinerejes.com E-mail: sustinere.jes@iain-surakarta.ac.id

RESEARCH PAPER

\title{
Resort based management Web GIS: Towards cyber conservation in Indonesia
}

\author{
Arie Vatresia ${ }^{1,2}{ }^{*}$, Jonathan P. Sadler ${ }^{1}$, Rendra Regen Rais ${ }^{3}$ \\ ${ }^{1}$ School of Geography, Earth and Environmental Sciences, University of Birmingham, Birmingham, UK \\ 2 Dept. of Informatics Engineering, University of Bengkulu, Indonesia \\ ${ }^{3}$ The Ministry of Environment and Forestry, Indonesia \\ Article history: \\ Received 01 December 2016 | Accepted 01 February 2017 | Available online 21 June 2017
}

\begin{abstract}
Biodiversity loss is a global issue and is especially of pressing concern in mega diverse countries, such as Indonesia. To prevent any further catastrophe, the Ministry of Forestry and Environment of Republic of Indonesia has been promoting the resort based management to be implemented in Indonesia to maximize the performance of conservation activity. The lack of data standardization made it hard to organize and manage archipelagic country that consist 17,504 islands with no technology provision in most of them. In this paper we develop a framework of integration mobile-web technology for biodiversity and conservation in Indonesia. We introduced a new framework to maintain the biodiversity and conservation data in Indonesia.
\end{abstract}

Keywords: Knowledge management; biodiversity informatics; framework; Indonesia conservation

\section{Introduction}

Indonesia is a country that has an extraordinary landscape and most biodiversity in the world second only to Brazil (Wiratno, 2013). It contains 17,504 islands with 50 conservation area spread across its five biggest islands. Indonesia is currently facing high deforestation rate, threatening the survival of its biodiversity (Jepson, 2001; Fuller, 2010; Margono, 2014). Some organisations and groups of people have been collecting and analysing data from Indonesia as part of their effort to halt the deforestation and biodiversity loss. Many acts of the Indonesian government, nongovernmental organisations, and public organisations have been contributing to solving the problem.

Unfortunately, researchers are challenged with some problems when conducting biodiversity study in Indonesia due to its expansive archipelagic territory. The first

${ }^{*}$ Corresponding author. E-mail: arie.vatresia@unib.ac.id

DOI 10.22515/sustinere.jes.v1i1.3 
problem is remote area. As a developing country, many conservation areas in Indonesia are forest and mostly located outside the coverage of electricity and telephone services. This condition is especially problematic when collecting data from a specific spot in a conflict area where conflicts between the government and other parties happened in enforcing the policy and rule in the real environment. Some of them occurred where the personnel were involved in the conservation area (Wiratno, 2013). Currently, the data was distributed by the forest ranger by submitting the report to higher body in the respective province. The national data was accumulated from all provinces in Indonesia.

The second problem is data standardisation. The need for standardised data in Indonesia is very crucial. Due to the significant responsibility in conservation activity, quite often different regions have different criteria for data specifications. Additionally, the change of the management also affects data standardisation. This varied data standard is hindering the process of gaining knowledge from the data. This situation worsens the quality of the conservation and biodiversity data in Indonesia, thus, difficult to acquire useful information that is of high importance to support the decision-making process.

The third problem is record limitation. Conservation activities in Indonesia are rarely equipped with adequate technology, leading to the limited data record. The limitation can be caused by the data age, validity, integration as well as the differences in data standardisations as mentioned above. The flawed forms to document the conservation activity also limit the record. Due to this record limitation, the distribution of biodiversity in Indonesia is remained unknown and difficult to predict. For that reason, it is also problematical to understand the pattern of biodiversity in Indonesia.

It is admitted by the Minister of The Ministry of Environmental and Forestry that Indonesia needs conservation technology to help in decision making for sustainable forest without disturbing Indonesia development scheme (Novrizal, 2016). The conservation scheme itself has a wide range of management and task, including how fast the top management can acquired updated information about the current condition of conservation. As a form of awareness to provide the information, government have built and launched some of the applications and websites to help the management of biodiversity and conservation activity in Indonesia, such as webgis.dephut.go.id, kehati.or.id, ibis.biologi.lipi.go.id, and nbin.lipi.go.id. They offer an interactive interface to observe the data collection of biodiversity and environment in Indonesia, even though some of the functions have not been working properly to provide essential information for public and research. The development of these application and software is a positive feedback from Indonesia to introduce the technology into the process of conservation and biodiversity management in Indonesia.

We realised that collecting the data with the implementation of technology does not mean we understand the whole problem of Indonesian environment and biodiversity (Wiratno, 2013 and Suryadi, 2014). On the other hand, we also believed that conservationist and ecologist could possibly neglect the process of data collection and data input quality. Kissling et al. (2015), Roberts and Hardisty (2012), and 
Leidenberger et al. (2015) said that there are two current challenges to process the biodiversity and environment data. The first challenge is for the ecologist and conservationist to see the pattern of sufficient data collected from many different resources to obtain the information and knowledge from the data. The other challenge is for the information scientist and engineer to set up the framework and act upon the algorithm accordingly to help other parties to analyse the data. In this paper, we develop the framework of standard data for conservation in Indonesia based on ontology method.

\section{Method and Framework Development}

The method of Design Science Research (DSR) adopted the philosophy of problem-solving paradigm rather than problem-understanding paradigm. It was developed to make the succeeding condition better than the previous one discussed before. The DSR process is described in Figure 1.

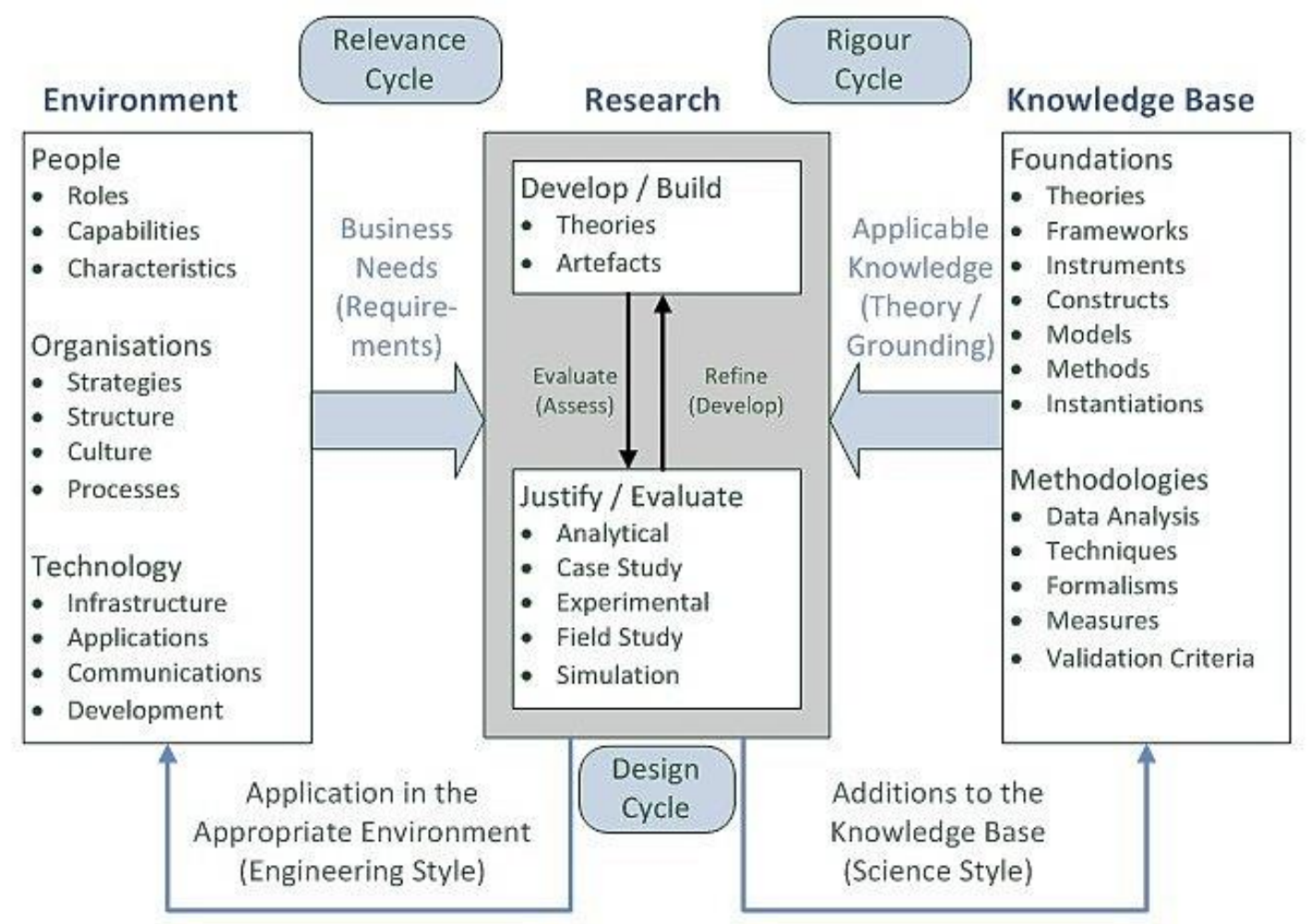

Figure 1. The DSR process (Havner, 2007)

The Design Science Research methodology is commonly used to develop the theories and artefact based on the problem occurrence in the organization. This method makes the research learned from the environment and knowledge base to provide the standard policy that suited to the organization condition. This also cable of bringing people, organization, and technology together so the environment can accept and adapt to the design and framework with relevancy. By using the environment of the system, the framework could map the business need and recognize the problem 
inside the system. The framework was also integrated with applicable knowledge that was initialized as the fundamental idea and theory of the system and organization.

This methodology contains three cycles that help the developer of the system and algorithm to suit the need of the organization. The relevance cycle is the process to appoint the requirements of the organization to provide the design and implementation of information system to be developed. In other hand, the rigor cycle is the process to confirm the innovation occurrence match with the fundamental knowledge that already exist within the organization. The design cycle is the process that would repeat the main cycles to provide the application that would be suitable within the organization and also add some new knowledge to the basic data to improve the next cycle of the routine. This three cycles make the learning process from the fact more possible to implement the better system into organization.

\subsection{Problem Description and Motivation}

Although there is still limited technologies adopted to maintain the forest and conservation in Indonesia (Pikiran Rakyat, 2015), Indonesia has a willingness to improve it, proven by the development of application and website as mentioned above. Despite the standard and guidance of data remains unknown, this condition indicates that there is an eagerness from the Indonesian government to improve the data availability and that many organisation has also realised its critical importance. The development of framework for cyber conservation and biodiversity activity in Indonesia aims to bridge the system availability and basic knowledge of Indonesia so it can approach the global goal of sustainable environment by managing the conservation and biodiversity itself.

In fact, the deforestation and forest management as well as conservation activity in Indonesia were centralized in The Ministry of Environment and Forestry of Indonesia and it has been trying to revolve the condition to be better. The latest management approach from the Ministry was the placement of the resort as the central tenet of the activity of conservation in Indonesia. This body will be the outer facing element that interacts with the people within the area. The aim of this decision can be easily understood as it would help the Ministry to collect biodiversity data and also identify areas of conflict. Furthermore, this policy aspires to bring back the nature of forest ranger activity in Indonesia that should be available inside the area. As Indonesia is vastly spread across around $5000 \mathrm{~km}$ from east to west with more than 17,000 islands to be managed, the framework must cover the need of real time data availability from every remote area in Indonesia without bureaucracy border and redundant process from manual input. In this research we use the cycle of the DSR method to provide and manage the process of information input to become useful knowledge for the ministry.

In this paper, the conservation and biodiversity framework is the focus of the research. The framework was made by analysing the system on the Ministry of Environmental and Forestry in Indonesia. Many applications have connected the Information Technology with the conservation activities. Bartlett et al, (2015), and Gutierrez et al. (2015) are some researchers that have been using them to help solving the problem in conservation, agriculture, and soil around the area and it has been 
showing improvement of performance and acceptance ever since. Moreover, the method of Management Effectiveness Tracking Tools (METT) that was initially introduced by Edition (2007) was adopted to support the analysis.

This approach would also be used to contribute to the effectiveness of protected area as an indicator for meeting the global targets. This method is broadly used by many conservation activities in the world as the primary method to be implemented in the conservation area. To support this method, The World Commission on Protected Areas also developed the framework to maximise and to improve the management of information flow in the potential protected area. It was produced by analysing the strength, weakness, opportunities, and threats around the protected area. The summary of the METT framework is described in Table 1.

Table 1. The element of management effectiveness tracking tools (METT)

\begin{tabular}{|c|c|c|c|}
\hline $\begin{array}{l}\text { Element of } \\
\text { Evaluation }\end{array}$ & Explanation & Criteria assessed & $\begin{array}{c}\text { Focus of } \\
\text { evaluation }\end{array}$ \\
\hline Context & $\begin{array}{l}\text { Where are we now? } \\
\text { Assessment of importance, threats and } \\
\text { policy environment }\end{array}$ & $\begin{array}{l}\text { - Significance } \\
\text { - Threats } \\
\text { - Vulnerability } \\
\text { - National context } \\
\text { - Partners }\end{array}$ & Status \\
\hline Planning & $\begin{array}{l}\text { Where do we want to be? } \\
\text { Assessment of protected area designs } \\
\text { and planning }\end{array}$ & $\begin{array}{l}\text { - Protected area } \\
\text { legislation and policy } \\
\text { - Protected area system } \\
\text { and design } \\
\text { - Reserve design } \\
\text { - Management planning }\end{array}$ & Appropriateness \\
\hline Inputs & $\begin{array}{l}\text { What do we need? } \\
\text { Assessment of resources needed to } \\
\text { carry out management }\end{array}$ & $\begin{array}{l}\text { - Resourcing of agency } \\
\text { - Resourcing of site }\end{array}$ & Resources \\
\hline Process & $\begin{array}{l}\text { How do we go about it? } \\
\text { Assessment of the way in which } \\
\text { management is conducted }\end{array}$ & $\begin{array}{l}\text { - Suitability of } \\
\text { management processes }\end{array}$ & $\begin{array}{l}\text { Efficiency and } \\
\text { appropriateness }\end{array}$ \\
\hline Outputs & $\begin{array}{l}\text { What were the results? } \\
\text { Assessment of the implementation of } \\
\text { management programmes and actions; } \\
\text { delivery of products and services }\end{array}$ & $\begin{array}{l}\text { - Results of management } \\
\text { actions } \\
\text { - Services and products }\end{array}$ & Effectiveness \\
\hline Outcomes & $\begin{array}{l}\text { What did we achieve? } \\
\text { Assessment of the outcomes and the } \\
\text { extent to which they achieved } \\
\text { objectives }\end{array}$ & $\begin{array}{l}\text { - Impacts: effects of } \\
\text { management in } \\
\text { relation to objectives }\end{array}$ & $\begin{array}{l}\text { Effectiveness } \\
\text { and } \\
\text { appropriateness }\end{array}$ \\
\hline
\end{tabular}

Aside from all of the limitations and challenges faced by the researchers to map the data in Indonesia, analysing and reviewing business process in the Ministry of Environmental and Forestry of Indonesia has been done. It resulted in the problem formulation as follows.

a. Different Sources

We realised that different systems are built with the different process of analysis. In the case of biodiversity and conservation in Indonesia, there are many sources of data to obtain from and to help the researchers achieve the information and knowledge. 


\section{b. Different Domains}

There are 50 national parks in Indonesia which are managed under different conditions. Each of national park has its own unique character yet cannot be separated one another.

\section{c. Different Infrastructure}

Although some of the National Parks in Indonesia already introduce the register system to manage the data, other national parks has their own version which is formulated by the domain bureau.

\subsection{Objectivities of Solutions}

Although the idea of Resort Based Management has been introduced by The Ministry of Environmental and Forestry in its strategic planning 2010-2014, its implementation is limited only in some of the national parks and standard research infrastructure in these areas is still insufficient. Considering these problems, Kissling et al., (2015) mentioned that to enable information processing, below requirements must be met:

\section{a. Advantageous yet easily processed data}

The process of information should be allowed to be used by many people that need the data. Simple data does not mean inappropriate to be used as research data. The more metadata generates the easier the data integration. The metadata itself were generated by the system to process the knowledge to be relevant information for the organization

\section{b. Semantically connected deforestation data}

The data of biodiversity loss, river flow area, and environment management should be connected each other with a particular connection. Thus could be helpful for higher authority to manage the policy and decision in the certain area.

\section{c. Easily optimized data}

Robert and Hardisty (2012) said that the core RI should be elastic and fault tolerant so it can make the composition of the service could be easier to be done. And the data should be easy to be optimised to meet the user requirements.

\section{d. Safe and reliable data}

Open accessed data should be available for every researcher when the system built by the organisation. Open access does not mean insecure in a political way. The data should be protected and authorised by particular administrator and user.

\section{Result}

\subsection{Design and Development}

Based on the previous steps, we develop the data management framework for conservation and biodiversity in Indonesia as described in Figure 2. The framework of data management was built by integrating the management tracking tools with the designed research methodology. In Figure 2 we can see several steps that would be involved in managing the data of conservation and biodiversity in Indonesia. In the 
following discussion, we describe data management steps. Each step discusses the environment and knowledge base aspects.

\section{a. Identification}

Environment. This step would be affected by the personal experience of the practitioner inside the organisation including the forest ranger, general officer, instructor, decision maker, and the leader of the organisation. This step would also need the interaction and connection between each component in the infrastructure.

Knowledge Based. This part would be involved in previous works in IT value, adaptive system, and IT governance practice inside the Ministry of Environmental and Forestry of Indonesia.

\section{b. Requirement and Analysis}

Environment. This step would be the necessity to share the concept of IT service and the relationship among infrastructure components as a part of ontology method. This phase also has to follow the procedure of anticipated ontology development inside there and should be formed as the competency questions that would be needed in next step of this data management. This step would also suggest supporting the IT ontology to support the IT value measurement.

Knowledge Based. The supporting document that would be helpful in this stage are the literature review on information structure, IT analysis, IT value, and enterprise model ontology.

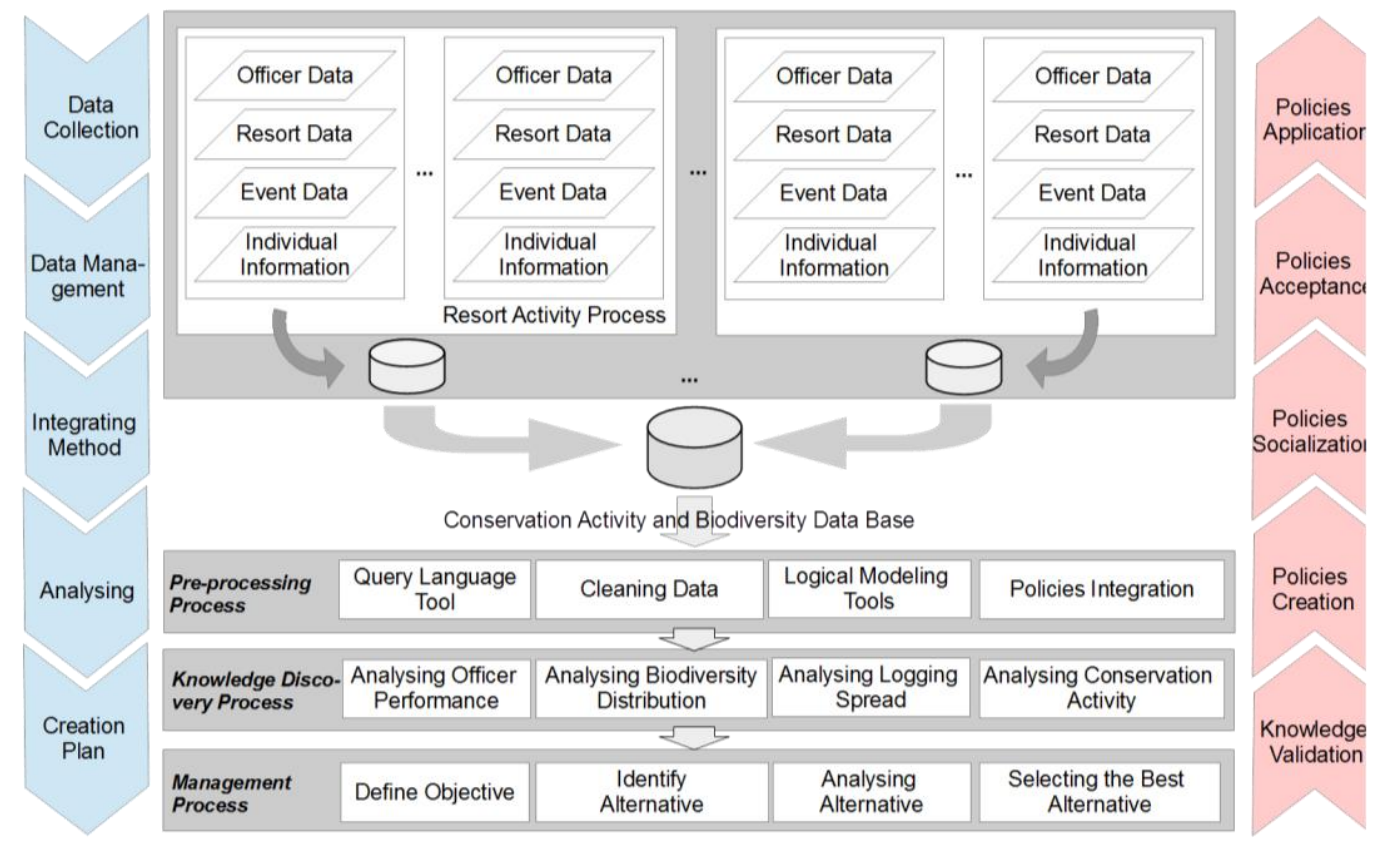

Figure 2. The Conservation and Biodiversity Data Management

\section{c. Design and Development}

Environment. This phase would produce the prototype of the system for IT value assesment and additional specification for a human resource as part of an organisation. It also needs the feedback and observation that acquired from the 
body of The Ministry of Environmental and Forestry in Indonesia. Moreover, it would contain the definition of conceptualization of key terms related to IT infrastructure, service, and business process.

Knowledge Based. This phase would involve the IT value theories and taxonomies to the ground ontology concept. The Ontology of Engineering process would also affect the existing taxonomy like COBIT or ITIL.

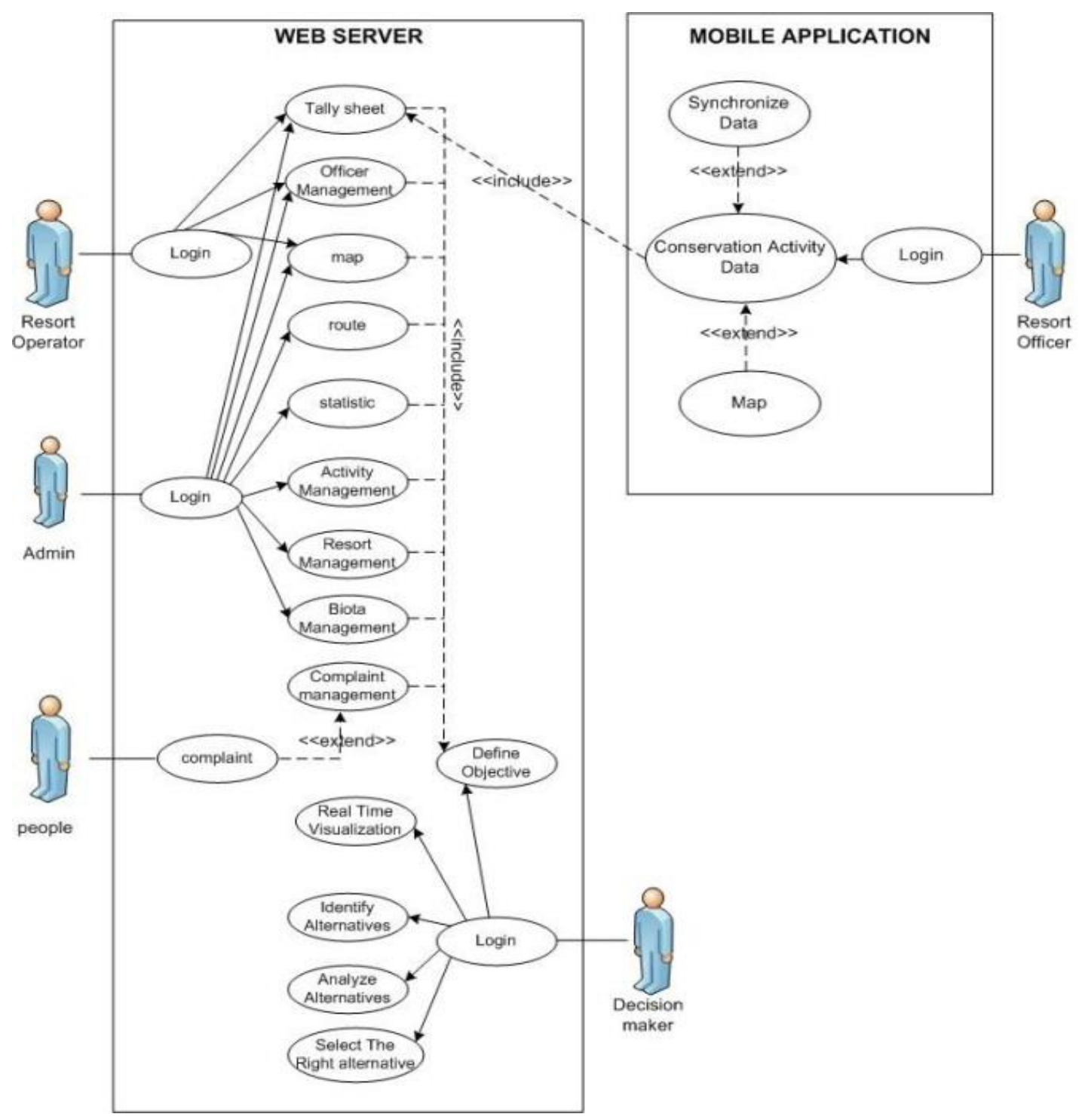

Figure 3. The system use case

The knowledge management is stored $42 \%$ on employees brain, $26 \%$ are in the paper document, $20 \%$ are in the electronic document, and $12 \%$ are in electronic knowledge (Ermine, 2010). Based on that research we believe that we cannot neglect the participation of human being to support a reliable system. The existence of the human in the mechanism of data processing should be the priority. Without the contribution from a user, the data would be just the utopia that can be money and time 
wasting. The synergistic of human and computer interaction would result in the better value of information and knowledge that can be used for future work. We describe the use case of the proposed of the system that should be built to help the problem in conservation and biodiversity in Indonesia in Figure 3. In the engineering phase, the activity diagram in Figure 4.

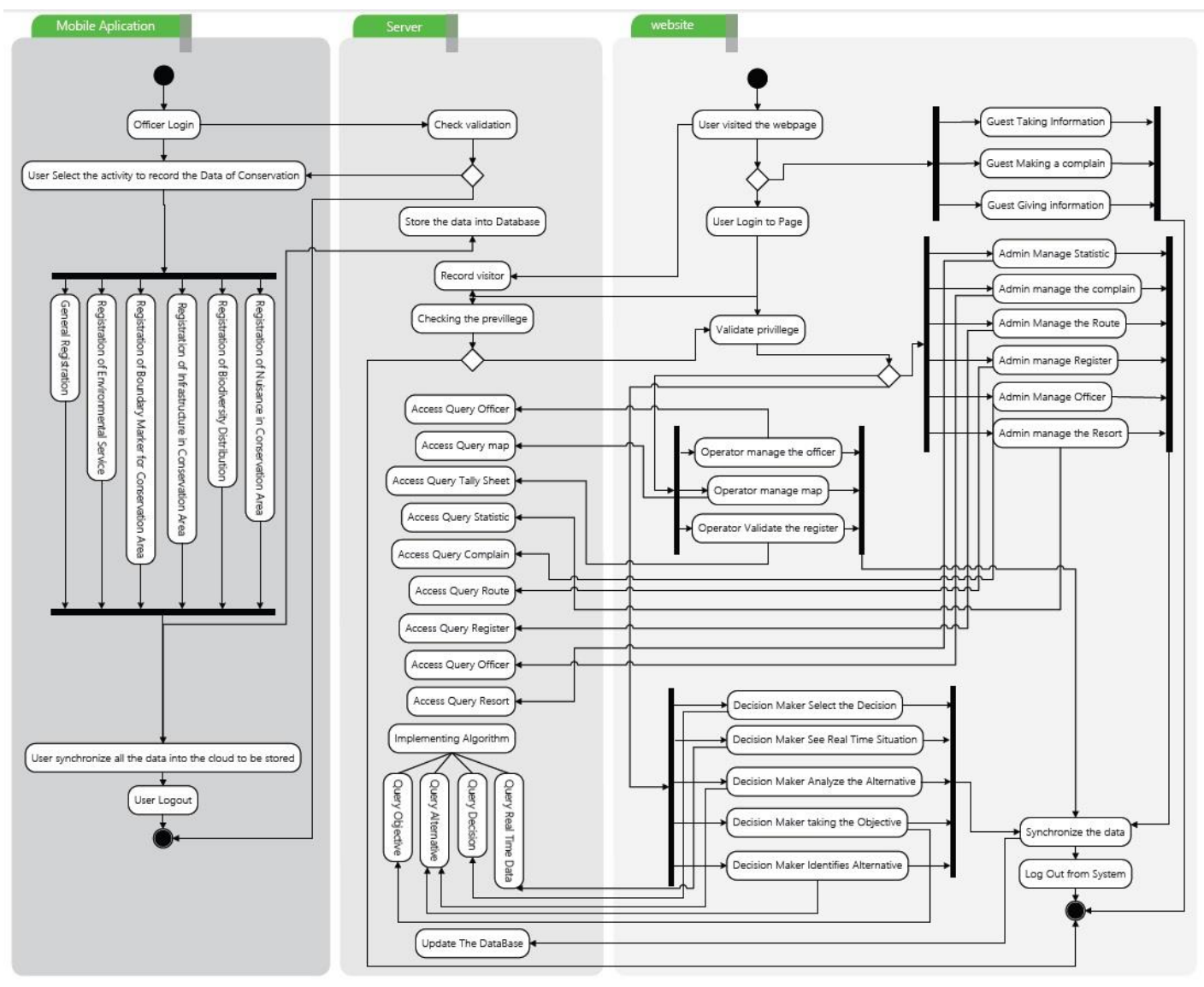

Figure 4. The activity diagram of the system

\subsection{Implementation and Evaluation}

After the process of developing the framework to become the standard of the Information System, it is used to assess a better management for conservation and biodiversity in Indonesia. However, the evaluation of the element still needs to be covered to assure the efficiency of the process. Based on the methodology of METT that are provided by the WWF in 2007, elements of evaluation was formulated as a guide to support all of the phase in the framework implementation.

\section{a. Context}

In this evaluation element, the Ministry, as the central of management biodiversity and conservation activity in Indonesia, must honestly address the problem that appeared within the organisation and other related organisations that have overlapped 
interest. By knowing the condition, the Ministry should be able to move forward to gain the solution of the addressed problem. Based on the problem addressed by the Ministry, the context of this process should be corresponded to the law and policy in Indonesia. Because of the main responsible of The Ministry of Environmental and Forestry in Indonesia is to maintain the sustainable environment in Indonesia, the context of the process should be forest management, protected island, biodiversity, and management area. By knowing and completing this evaluation, the ministry must have a map of partners and threat organisations that would influence the process of the system, including, non-governmental organisation, pulp company, wood company, palm oil company, and all related company that would mainly use the resource of Indonesia forest. By managing this process the Ministry could focus and make some priority scales on how vulnerable the area.

\section{b. Planning}

The aim of the conservation in Indonesia are to achieve the global goal of managing forest and biodiversity, to reduce the green-house effect and minimize carbon emission to make the earth a better place to live. By knowing the status of the land and make the status of the land and forest become clearer, the Ministry needs to involved the people of Indonesia and make them aware about the importance of the plan and to achieve the goal that already defined. Furthermore, the Ministry should also give a clear clue about the protected area design and implement the recent policy of Resort Based Management to flow the information into the useful knowledge.

\section{a. Input}

Resort Based Management System formulated the input that would be needed to be useful when the higher authority need to apply the policy. The inputs are:

- Forest degradation due to illegal logging

- Forest degradation due to nature disaster

- Animal hunting

- Lost and died animal

- Animal distribution

- Water resource

- Mooring

- Infringement and violation
- Area infrastructures

- Conservation area licenses

- Loggers

- Tourist attraction and environmental service

- Boundary sign

- Diving spot, coral destruction, fishing boat, mangrove destruction, seaweed, and water pollution

All of the information needed by the Ministry should be provided by the internal member of the Ministry or protected area staff due to the basic idea of resort based management policy. If the Ministry finds the sharing data could help the input process, some additional data could be obtained by trusted organisation that has the same aim and vision to protect the process from misleading outcomes. 


\section{b. Process}

The process of the evaluated value is by doing the process based on the framework that already built as a standard process. It has to involve the three cycles of the method that already implemented on the system framework that we built. By following the step of the framework, the processes of managing the biodiversity and conservation activity are performed.

\section{c. Output}

The output of the process should be measured by the decreasing rate of deforestation, decreasing intensity of carbon emission, and maintaining the richness level of biodiversity and increasing number of animal sanctuary and protected area to achieve the land stability. The output could also be obtained by implementing relevant policy to be accepted easily by the people and corresponded to the need of the problem in Indonesia. For example, there is a constraint to maintain the forest in Indonesia due to the increasing rate of population. By implementing the framework, Indonesia could finalize the policy to keep maintaining the forest area and also stabilizing the need of housing and income rate so the people no need to degrade land by shifting cultivation nor planting palm oil as an income.

\section{d. Outcomes}

By implementing all of the process in the framework, it would also be beneficial to have the law enforcement in Indonesia being enacted to maintain the stability of the cycle process in biodiversity and conservation activity.

\section{Discussion and Conclusion}

In this paper, the problem identification and the proposed model has been explained to support the cyber conservation in Indonesia. This initial project would be an emerging project that involves multidisciplinary fields to contribute to the development of cyber conservation. It is important to adopt this framework design for the development of the Information Technology and system in the Ministry of Environmental and Forestry in Indonesia. Further research of this framework would be its implementation on the system so it can help the process of data management inside the body. The result of our interviews inside the government body also agreed to induce the application inside the IT infrastructure and business process elements in the Ministry.

The description about basic information on the Ministry of Environmental and Forestry is the essential step as the organisation just merged together in the new regime and implementation. The aim and vision must be addressed to make the process of system implementation become more efficient. The organisation should also recognize the overlapping infrastructure that needs to be renewed and to be expanded based on the requirement of the organisation. The organisation should adapt with the situation quicker to allow some changes to be directed by the higher authority.

To make a big change to be better might not be an easy task. The readiness of the organisation to induce the technology acceptance should be improved. Providing some training and socialization about the new approach of the organisation for the personnel could help their understanding. It has to adopt some of the methodologies to make the 
system of organisation dynamic and familiar with the change. It has to accept the possibility of multidisciplinary role, and should be working side by side to accept the vision of cyber conservation in Indonesia. Furthermore, the initiation of the public engagement about the awareness and the aim of the organisation should be known by public by making them as the source to enforce the law in Indonesia.

To achieve the complete performance of the framework, the organisation should spare some fund to implement step by step process that have been formulated in this paper. As the process itself contain some cycles, the organisation does not have to force to implement all of the cycles into one step because it can make the organisation have no sturdy base of knowledge that would affect the other cycles performance. Once the organisation completed all of the steps on the framework, the process would keep cycling as the time passes; the problem occurs must be adopted inside the system as the learning process to make the system more mature in order to provide the policy a basis for consideration. In any case, the full implementation of the ontology of the framework already developed can only be achieved through the use of the software tools that allow the reasoning.

\section{Acknowledgement}

We would like to thank our sources, people who active on The Resort Based Management who willing to share the idea and working plan to protect the biodiversity and conservation activity in Indonesia. We would also like to thank The Ministry of Research, Technology, and Higher Education for funding the research.

\section{Reference}

Bartlett, A. C., Andales, A. A., Arabi, M., \& Bauder, T. A. (2015). A smartphone app to extend use of a cloud-based irrigation scheduling tool. Computers and Electronics in Agriculture, 111, 127-130. http://doi.org/10.1016/j.compag.2014.12.021

Ermine, J. L. (2010). Introduction to Knowledge Management. Trends in Enterprise Knowledge Management, (June), 21-43. http://doi.org/10.1002/9780470612132.ch1

Fuller, D. O., Meijaard, E. M., Christy, L., \& Jessup, T. C. (2010). Spatial assessment of threats to biodiversity within East Kalimantan, Indonesia. Applied Geography, 30(3), 416425. http://doi.org/http://dx.doi.org/10.1016/j.apgeog.2009.11.004

Gutierrez, J., Villa-Medina, J. F., Lopez-Guzman, A., \& Porta-Gandara, M. A. (2015). Smartphone Irrigation Sensor. IEEE Sensors Journal, 15(9), 5122-5127. http://doi.org/10.1109/JSEN.2015.2435516

Havner, A. R. (2007). A Three Cycle View of Design Science Research. Scandinavian Journal of Information Systems, 19(2), 87-92. http://doi.org/http://aisel.aisnet.org/sjis/vol19/iss2/4

Jepson, P., Jarvie, J. K., MacKinnon, K., \& Monk, K. A. (2001). Essays on science and society. The end for Indonesia's lowland forests? Science, 292(5518), 859-861. Retrieved from http://www.ncbi.nlm.nih.gov/pubmed/11341279

Kissling, W. D., Hardisty, A., García, E. A., Santamaria, M., De Leo, F., Pesole, G., ... Los, W. (2015). Towards global interoperability for supporting biodiversity research on 
essential biodiversity variables (EBVs). Biodiversity, 8386(April 2016), 1-9. http://doi.org/10.1080/14888386.2015.1068709

Leidenberger, S., Obst, M., Kulawik, R., Stelzer, K., Heyer, K., Hardisty, A., \& Bourlat, S. J. (2015). Evaluating the potential of ecological niche modelling as a component in marine non-indigenous species risk assessments. Marine Pollution Bulletin, 97(1-2), 470-487. http://doi.org/10.1016/j.marpolbul.2015.04.033

Margono, B. A., Turubanova, S., Zhuravleva, I., Potapov, P., Tyukavina, A., Baccini, A., ... Hansen, M. C. (2012). Mapping and monitoring deforestation and forest degradation in Sumatra (Indonesia) using Landsat time series data sets from 1990 to 2010. Environment Research Letter2, 7(3), 34010.

Roberts, D., \& Hardisty, A. (2012). Data accessibility: Getting a handle on biological data. Nature, 484(7394).

Suryadi, S. (2014). Knowledge Management (2): Pembelajaran kepada Balai Besar Konservasi Sumber Daya Alam Nusa Tenggara Timur. Retrieved from https://kawasankonservasi.wordpress.com/tag/ knowledge-management/

Wiratno. (2013). Resort Based Management: Learning Process from East Nusa Tenggara. The Ministry of Forestry Indonesia.

Wollaston, V. (2015). Animals on the brink of extinction: World maps reveal the countries with the most endangered mammals. Retrieved September 8, 2015, from http://www.dailymail.co.uk/ sciencetech/article-\%0A3037027/Animals-brinkextinction-World-maps-reveal-countries-endangered-mammals.html\%0A

WWF. (2007). Management Effectiveness Tracking Tool. Diversity, (July), 1-22. Retrieved from assets.panda.org/ 